This is an electronic reprint of the original article. This reprint may differ from the original in pagination and typographic detail.

Author(s): Ośmiałowski, Borys; Zakrzewska, Anna; Jędrzejewska, Beata; Grabarz, Anna; Zaleśny, Robert; Bartkowiak, Wojciech; Kolehmainen, Erkki

Title: $\quad$ Influence of Substituent and Benzoannulation on Photophysical Properties of 1Benzoylmethyleneisoquinoline Difluoroborates

Year: $\quad 2015$

Version:

Please cite the original version:

Ośmiałowski, B., Zakrzewska, A., Jędrzejewska, B., Grabarz, A., Zaleśny, R., Bartkowiak, W., \& Kolehmainen, E. (2015). Influence of Substituent and Benzoannulation on Photophysical Properties of 1-Benzoylmethyleneisoquinoline Difluoroborates. Journal of Organic Chemistry, 80(4), 2072-2080.

https://doi.org/10.1021/jo502244j

All material supplied via JYX is protected by copyright and other intellectual property rights, and duplication or sale of all or part of any of the repository collections is not permitted, except that material may be duplicated by you for your research use or educational purposes in electronic or print form. You must obtain permission for any other use. Electronic or print copies may not be offered, whether for sale or otherwise to anyone who is not an authorised user. 


\section{The influence of substituent and benzoannulation on photophysical} properties of 1-benzoylmethyleneisoquinoline difluoroborates

Borys Osmialowski, Anna Zakrzewska, Beata Jedrzejewska, Anna Maria Grabarz, Robert Zalesny, Wojciech Bartkowiak, and Erkki Kolehmainen

J. Org. Chem., Just Accepted Manuscript • DOI: 10.1021/jo502244j • Publication Date (Web): 29 Jan 2015

Downloaded from http://pubs.acs.org on February 3, 2015

\section{Just Accepted}

"Just Accepted" manuscripts have been peer-reviewed and accepted for publication. They are posted online prior to technical editing, formatting for publication and author proofing. The American Chemical Society provides "Just Accepted" as a free service to the research community to expedite the dissemination of scientific material as soon as possible after acceptance. "Just Accepted" manuscripts appear in full in PDF format accompanied by an HTML abstract. "Just Accepted" manuscripts have been fully peer reviewed, but should not be considered the official version of record. They are accessible to all readers and citable by the Digital Object Identifier (DOIB). "Just Accepted" is an optional service offered to authors. Therefore, the "Just Accepted" Web site may not include all articles that will be published in the journal. After a manuscript is technically edited and formatted, it will be removed from the "Just Accepted" Web site and published as an ASAP article. Note that technical editing may introduce minor changes to the manuscript text and/or graphics which could affect content, and all legal disclaimers and ethical guidelines that apply to the journal pertain. ACS cannot be held responsible for errors or consequences arising from the use of information contained in these "Just Accepted" manuscripts. 


\title{
The influence of substituent and benzoannulation on photophysical properties of 1-benzoylmethyleneisoquinoline difluoroborates
}

\author{
Borys Ośmiałowski ${ }^{a},{ }^{*}$ Anna Zakrzewska $^{a}$, Beata Jędrzejewska ${ }^{a}$, \\ Anna Grabarz ${ }^{b}$, Robert Zaleśny ${ }^{b, c}$, Wojciech Bartkowiak $^{b}$, Erkki Kolehmainen ${ }^{d}$ \\ ${ }^{a}$ Faculty of Chemical Technology and Engineering, UTP University of Science and \\ Technology, Seminaryjna 3, PL-85326 Bydgoszcz, Poland \\ e-mail: borys.osmialowski@utp.edu.pl or borys.osmialowski@gmail.com \\ ${ }^{b}$ Faculty of Chemistry, Wrocław University of Technology, Wyb. Wyspiańskiego 27, \\ PL-50370 Wrocław, Poland \\ ${ }^{c}$ Division of Theoretical Chemistry and Biology, School of Biotechnology, Royal \\ Institute of Technology, SE-10691 Stockholm, Sweden \\ ${ }^{d}$ Department of Chemistry, P.O. Box 35, FI-40014 University of Jyväskylä, Finland
}

\section{Graphical Abstract}

The photophysical properties of<smiles>[R]OB(F)/C(=C\c1c2ccccc2cc[n+]1F)c1ccccc1</smiles><smiles></smiles>

Abstract

A series of 1-benzoylmethyleneisoquinoline difluoroborates were synthesized and their photophysical properties were determined. The effect of the substituent and 
benzoannulation on their properties was investigated to make a comparison with recently published results focused on related quinolines. The photophysical properties of isoquinoline derivatives differ from those of quinolines and most pronounced differences are found for the fluorescence quantum yields. Both, experimental and theoretical approaches were used to explain the observed photophysical properties.

\section{Introduction}

Dyes carrying $\mathrm{BF}_{2}$ moiety are known to be fluorescent. Among them the most common group are the BODIPY dyes. ${ }^{1-3}$ Although plethora of studies were devoted to BODIPYs, these dyes are still in a limelight. The intense studies concern not only their absorption and fluorescence properties but also, for example, electrogenerated chemiluminescence. ${ }^{4}$ On the other hand, studies for the $\mathrm{BF}_{2}$-carrying fluorescent dyes different from BODIPYs are rare. Very recently the first survey on these molecules has been published by Ziessel et $a l .^{5}$ Moreover, there are some attempts to clarify their properties by computational approaches. ${ }^{6-8}$ Thus there is still a need to investigate, how their properties can be tuned in order to obtain desired photophysical characteristics. This is especially important for the fluorescence microscopy ${ }^{9}$, anion sensing applications ${ }^{10,11}$ or bio-labeling ${ }^{12}$, photodynamic therapy ${ }^{3}$, solar cells ${ }^{13,14}$ to name a few. The compounds studied now contain the $\mathrm{NBF}_{2} \mathrm{O}$ moiety. ${ }^{15-21}$ In literature there exist reports on compounds where $\mathrm{BF}_{2}$-group is chelated also symmetrically in $\mathrm{NBF}_{2} \mathrm{~N}^{22-25}$ and $\mathrm{OBF}_{2} \mathrm{O}^{26-29}$ moieties. Also molecules carrying $\mathrm{NBF}_{2} \mathrm{O}$ fragment, especially imines based on a hydroxyl-containing Schiff bases, are known. ${ }^{30-33}$

Tailoring molecular properties by relatively simple synthetic procedures is highly desirable. Systematic change of a substituent may be a successful route in 
many instances. On the other hand, the benzoannulation may also possess a crucial role in case of $\pi$-conjugated molecules, ${ }^{34-39}$ where it is known to have a fundamental impact (qualitative and quantitative) on the properties of compounds exhibiting tautomerism, for example, in heterocyclic ketones. ${ }^{37,40-43}$ Presumably, the properties of $\mathrm{BF}_{2}$-carrying molecules may also be tuned in this way. This is due to the fact that proton involved in the intramolecular hydrogen bonding ${ }^{40,41}$ can be easily replaced by another acid such as $\mathrm{BF}_{2}^{+}$cation. The proton-to- $B F_{2}$ exchange thus creates an opportunity to synthesize a number of new dyes. There are several publications on benzoannulation of the BODIPY core and its influence on photophysical properties of these molecules. ${ }^{44-48}$ This was the inspiration to study the isomers of 2benzoylmethylenequinoline difluoroborates studied by us recently ${ }^{49}$ id est. the 1benzoylmethyleneisoquinoline derivatives. It is worth mentioning that the effect of $\pi$ electron conjugation on the fluorescence quantum yield was studied on model compounds. ${ }^{50}$ On the other hand, to the best of our knowledge, no detailed studies are presented on the effect of structural isomerism on photophysical properties of $\mathrm{BF}_{2}$ carrying molecules. This leads to a hypothesis that both the length and the conjugation route should be taken into account when designing fluorescent molecules. Chart 1 depicts 1-benzoylmethyleneisoquinoline difluoroborates and their numbering. The synthesis of the parent 1-benzoylmethyleneisoquinolines was performed as described elsewhere for similar compounds. ${ }^{51}$ The conversion of these substrates into fluorescent $\mathrm{BF}_{2}$-carrying molecules was performed as in an earlier study. ${ }^{49,52}$ 


\section{Results and Discussion}

\section{Linear Photophysical Properties}

The photophysical properties of compounds 1-8 (Chart 1) were studied in chloroform. This solvent is known to prevent boron-ligand dissociation, exciplex formation, or photochemical reactions possible in solvents containing Lewis bases, aromatic rings, or double bonds. ${ }^{53}$ Moreover, the self-aggregation is not preferred in dilute solutions as it has already been demonstrated for quinoline derivatives. ${ }^{49}$ Figure 1 shows the absorption spectra of $\mathbf{1 - 8}$ and corresponding values are presented in Table 1. The molecules show absorption spectra in solution characterized by two distinct bands, the main band existing within the range 330-500 $\mathrm{nm}$ depending on the substituent and the second band at about 300-320 nm. Absorption spectra of complexes 2-8 exhibit fine structure although is not as distinct as in quinoline isomers, whereas 1 exhibits almost structureless band with maximum close to $460 \mathrm{~nm}$. Additionally, all eight complexes have high extinction coefficients (26400-38800 M${ }^{1} \mathrm{~cm}^{-1}$ ), which is typical for $\pi \rightarrow \pi^{*}$ transitions (Figure 1). Except 1, the shape of the absorption spectra remains very similar to the parent compound $(\mathrm{R}=\mathrm{H})$ and it is dependent on the electron-withdrawing or electron-releasing group at different 
positions in the phenyl ring. The absorption maximum and its intensity, however, differ among the studied set of compounds.

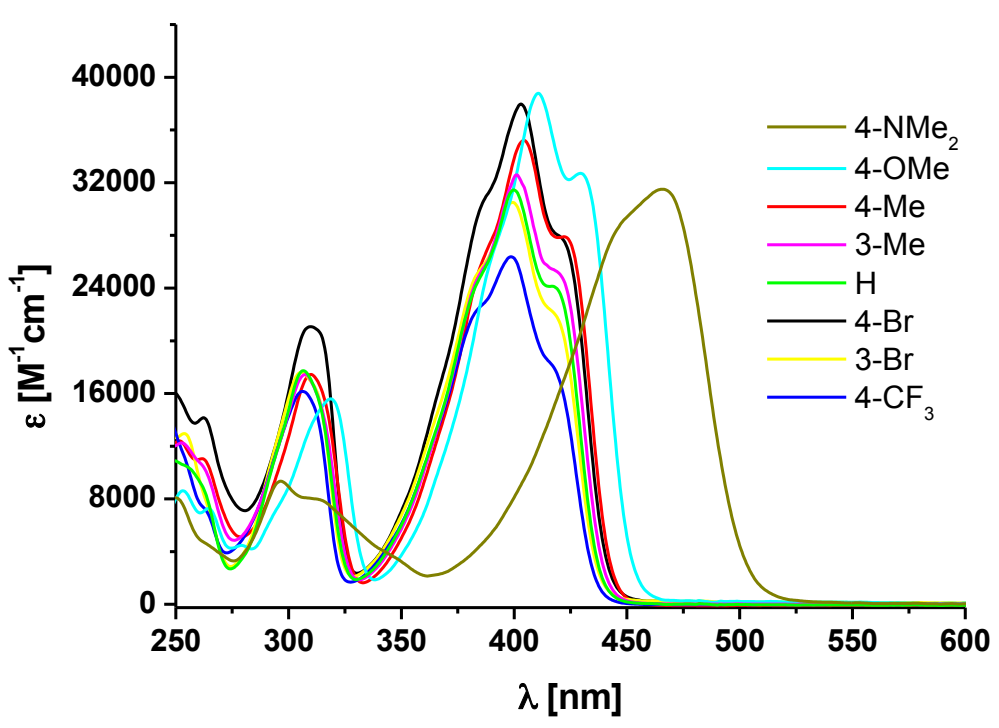

Figure 1. The electronic absorption spectra of 1-8 in $\mathrm{CHCl}_{3}$

In order to evaluate the effect of the different substituents on the linear optical properties, $-\mathrm{CF}_{3}$ was used as a benchmark acceptor group, as this moiety is the strongest acceptor in the series. In comparison with others, $8\left(4-\mathrm{CF}_{3}\right)$ shows similar but blue-shifted and less intense absorption band. Absorption at $\lambda_{\max }$ was found to progressively shift to longer wavelength upon replacing this substituent by weaker electron-withdrawing $(\mathrm{Br})$ and then electron-releasing (4-Me, 4-OMe, 4- $\mathrm{NMe}_{2}$ ) substituents (Table 1). This effect was accompanied by increase of the absorption intensity. A considerable red shift of the major absorption band was observed for compound $1\left(4-\mathrm{NMe}_{2}\right)$ (Figures 1-2). The 4-NMe 2 substituent causes a $66 \mathrm{~nm}$ red shift in absorption relative to the parent compound 5. This result indicates that the absorption arises from polarized $\pi-\pi^{*}$ transition in the $\mathrm{NMe}_{2}$ substituted molecule. The character of this transition will be discussed in more detail in the subsequent 
section. The significant density reorganization upon excitation was prevented after the addition of gaseous $\mathrm{HCl}$ into the measurement cell (Figure 2) and formation of the 4$\mathrm{NMe}_{2} \mathrm{H}^{+}$cation. The absorption maximum of the $4-\mathrm{NMe}_{2} \mathrm{H}^{+}$derivative was blue shifted when compared with the free base and the unsubstituted congener (5). Similarly with another report ${ }^{49}$, this reveals that the $4-\mathrm{NMe}_{2} \mathrm{H}^{+}$group has a weak electron-acceptor properties, which is in agreement with its cationic character. This effect retracts after the addition of gaseous ammonia to a solution of protonated $\mathbf{1}$. The similar effect was observed for 2-benzoyl(4-dimethylamino)methylenequinoline difluoroborate. $^{49}$

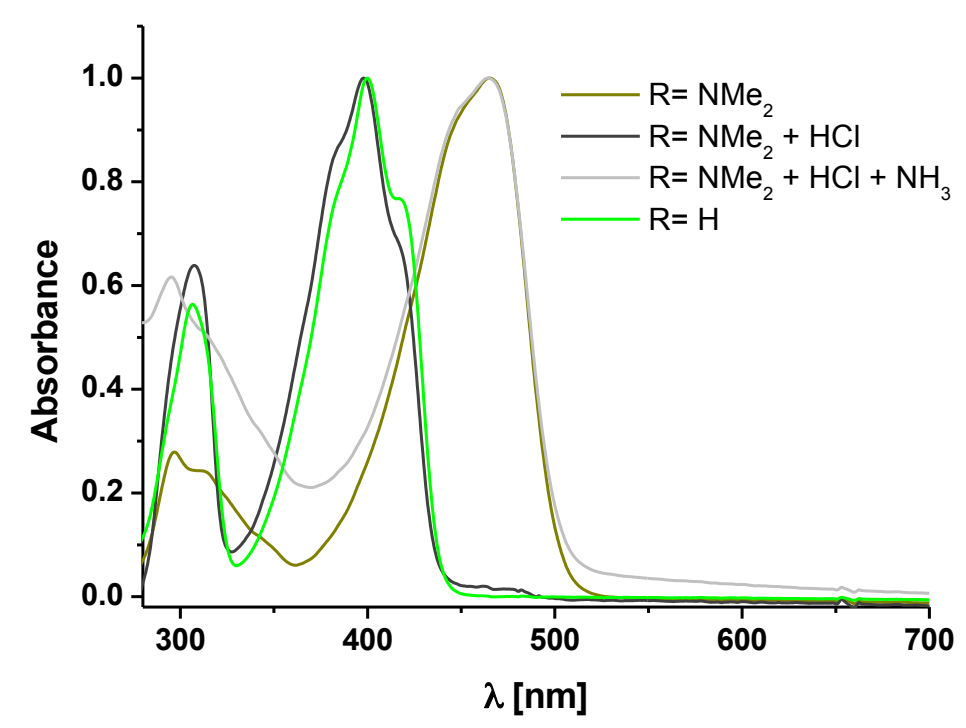

Figure 2. The comparison of the electronic absorption spectra of the parent compound (5), 4-NMe 2 (1) derivative, its $\mathrm{HCl}$ salt $(\mathbf{1}+\mathrm{HCl})$ and then neutralized with gaseous ammonia $\left(\mathbf{1}+\mathrm{HCl}+\mathrm{NH}_{3}\right)$

Likewise, the emission spectra and fluorescence lifetimes of 1-8 were measured in chloroform. The results are given in Figure 3 and Table 1. All compounds exhibit fluorescence ranging from blue to green region. Figure 3 compares the parent compound $(\mathrm{R}=\mathrm{H})$ with its derivatives containing electron-withdrawing and electron- 
donating groups to explore substituent effects on fluorescence spectra. As for the absorption spectra of $\mathbf{1 - 8}$, decreasing acceping strength and increasing donating ability of the substituent results in stronger and red-shifted emission. Among them 1 and 2 exhibit the strongest fluorescence, whereas the weakest emission occurs for complex containing the $4-\mathrm{CF}_{3}$ substituent. However, the fluorescence of $\mathbf{1}\left(4-\mathrm{NMe}_{2}\right)$ is different from the others because emission spectra of $\mathbf{1}$ shows a unstructured band (corresponding Stokes shift is $1943 \mathrm{~cm}^{-1}$ ). The same is observed in many other compounds including BODIPY dyes after the introduction of strong electron-donating amino group. ${ }^{54-58}$

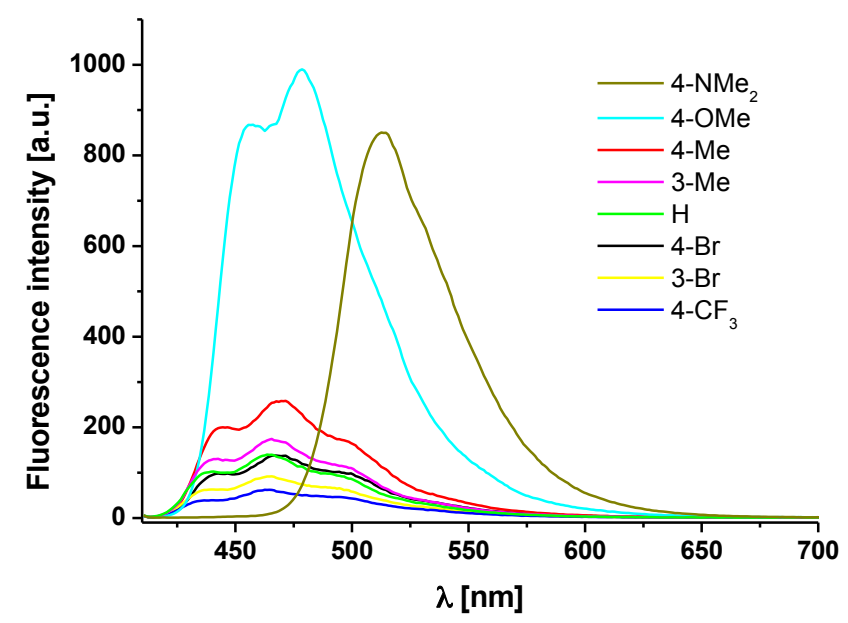

Figure 3. The fluorescence spectra of 1-8 (3-4 $[\mu \mathrm{M}])$ in $\mathrm{CHCl}_{3} \lambda_{\mathrm{ex}}=404 \mathrm{~nm}$

A mirror symmetry holds between the absorption and emission spectra as shown in Figure 4 (for compound 5, remaining spectra are given in SI) suggesting a weak structural relaxation of the Franck-Condon singlet excited state. 


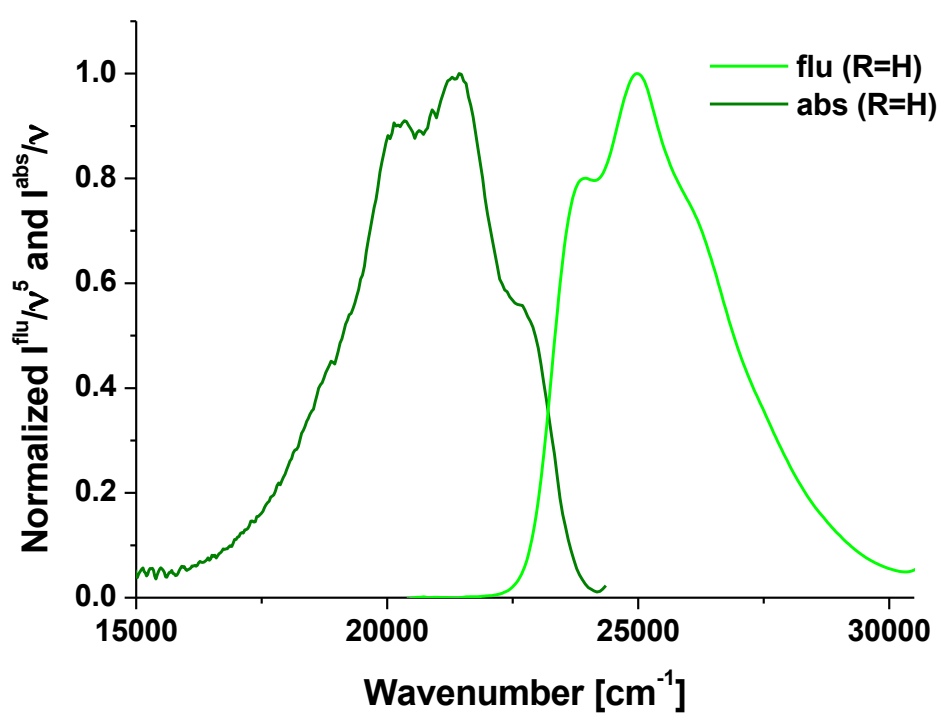

Figure 4. The normalized and scaled ${ }^{59,60}$ electronic absorption and fluorescence spectra of 5 in $\mathrm{CHCl}_{3}$

Table 1. The photophysical data ${ }^{a}$ for compounds 1-8

\begin{tabular}{llrllllllllll}
\hline No & Substituent & $\lambda_{\max }^{A b}$ & $\lambda_{\max }^{F l}$ & $\Delta v^{l}$ & $\Delta v^{2}$ & $\phi_{F l}$ & \multicolumn{1}{c}{$\tau_{1}$} & $\tau_{2}$ & $\tau_{a v}$ & $\chi^{2}$ & $k_{r}$ & $k_{n r}$ \\
& & & & & & & $\alpha_{1}$ & $\alpha_{2}$ & & & & \\
& & $\varepsilon^{*} 10^{4}$ & & & & & & & & & & \\
\hline $\mathbf{1}$ & $4-\mathrm{NMe}_{2}$ & 466 & & & & & 458 & 2427 & & & & \\
& & 3.15 & 512.4 & $1943^{\mathrm{b}}$ & 0.743 & 4.33 & 95.67 & 2341.7 & 1.83 & 3.17 & 1.10 \\
$\mathbf{2}$ & $4-\mathrm{OMe}$ & 410.5 & & & & & 405 & 1061 & & & & \\
& & 3.88 & 478.2 & 1320 & 3449 & 0.313 & 15.75 & 84.25 & 957.7 & 1.29 & 3.26 & 7.18 \\
$\mathbf{3}$ & $4-\mathrm{Me}$ & 404 & & & & & 348 & 747 & & & & \\
& & 3.52 & 471 & 1113 & 3521 & 0.087 & 92.82 & 7.18 & 376.7 & 1.28 & 2.32 & 24.23 \\
$\mathbf{4}$ & $3-\mathrm{Me}$ & 401.5 & & & & & 242 & 825 & & & & \\
& & 3.26 & 464.8 & 1077 & 3392 & 0.060 & 98.27 & 1.73 & 252.1 & 1.17 & 2.37 & 37.30 \\
$\mathbf{5}$ & $\mathrm{H}$ & 400 & & & & & 191 & 1109 & & & & \\
& & 3.14 & 463.2 & 1139 & 3411 & 0.046 & 98.77 & 1.23 & 202.3 & 1.16 & 2.28 & 47.15 \\
$\mathbf{6}$ & $4-\mathrm{Br}$ & 403 & & & & & 211 & 1374 & & & & \\
& & 3.80 & 466.4 & 1118 & 3373 & 0.049 & 98.19 & 1.81 & 232.1 & 1.12 & 2.10 & 41.00 \\
$\mathbf{7}$ & $3-\mathrm{Br}$ & 399.5 & & & & & 154 & 1249 & & & & \\
& & 3.05 & 465 & 1082 & 3526 & 0.033 & 97.33 & 2.67 & 183.2 & 1.50 & 1.82 & 52.76 \\
$\mathbf{8}$ & $4-\mathrm{CF} F_{3}$ & 398.5 & & & & & 127 & 1053 & & & & \\
& & 2.64 & 464.6 & 1092 & 3570 & 0.026 & 98.63 & 1.37 & 139.7 & 1.20 & 1.88 & 69.71 \\
\hline
\end{tabular}


a - Absorption $\left(\lambda_{\max }^{A b} ; n m\right)$, Fluorescence Maxima $\left(\lambda_{\max }^{F l} ; \mathrm{nm}\right)$, shift $\left(\Delta v, \mathrm{~cm}^{-1}\right)$, Maximum Extinction Coefficient $\left(\varepsilon ; M^{-1} \mathrm{~cm}^{-1}\right)$, Fluorescence Quantum Yield $\left(\phi_{F l}\right)$, Fluorescence Lifetime $(\tau ; p s)$, their amplitudes $(\alpha)$ and correlation coefficients $\left(\chi^{2}\right)$, Radiative $\left(k_{r} ; 10^{8} \mathrm{~s}^{-1}\right)$ and Non-radiative $\left(k_{n} ; 10^{8} \mathrm{~s}^{-1}\right)$ Rate Constants. ${ }^{\text {b }}$ difference between positions of the band maxima of the absorption and emission spectra of 4-NMe 2 .

The fluorescence quantum yield was determined relative to coumarine 1 quantum counter $\left(\phi_{\text {ref }}=0.64\right)$ with excitation at $404 \mathrm{~nm}$. Derivatives 1 and 2 exhibit good fluorescence quantum yield $(0.74$ and 0.31$)$ whereas for the others it is lower by one order of magnitude.

Figure 5 shows the biexponential fluorescence decay curve for $\mathbf{5}$. The same is used for the fitting of other derivatives. An additional long-lived component that appeared in these compounds suggests a complex photophysical processes. The fluorescence lifetimes measured by time correlated single photon counting method are shown in Table 1 above.

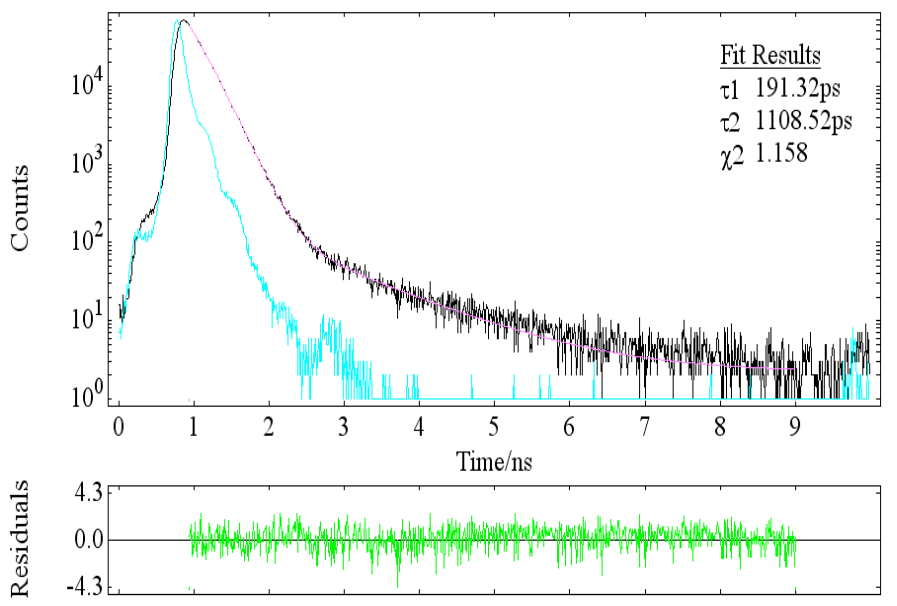

Figure 5. The fluorescence decay curve for 5 recorded in $\mathrm{CHCl}_{3} ; \lambda_{\mathrm{ex}}=404 \mathrm{~nm} ; \lambda_{\mathrm{em}}=$ $450 \mathrm{~nm}$

In the parent compound (5), $\phi_{\mathrm{Fl}}$ and $\tau_{\mathrm{Fl}}$ are 0.046 and 191 ps (major component), respectively. These values are diminished to 0.026 and $127 \mathrm{ps}$, respectively, when the 4- $\mathrm{CF}_{3}$ group is present $(\mathbf{8})$. Hence, the rate constant of radiative $k_{\mathrm{r}}$ deactivation is decreased from $2.28 \times 10^{8}$ to $1.82 \times 10^{8} \mathrm{~s}^{-1}$, respectively caused by strongly electron- 
withdrawing character of the substituent. On the other hand, introducing an electronreleasing substituent enhances the fluorescence quantum yields, lifetimes and Stokes' shift, e.g. for $4-\mathrm{NMe}_{2}$ the $\phi_{\mathrm{Fl}}=0.74, \tau_{\mathrm{Fl}}=2427 \mathrm{ps}$ (major component of different nature than that in 3-8, see Table 1 for $\tau_{1}$ and $\tau_{2}$ ) and $\Delta \nu=1943 \mathrm{~cm}^{-1}$. In both $\phi_{\mathrm{Fl}}$ and $\tau_{\mathrm{Fl}}$ show the monotonous increase with the increase in electron-donating abilities of the substituent. Additionally, the data compiled in Table 1 show that for tested compounds the non-radiative transition rates are of the same order as the radiative ones only for $\mathbf{1}$ and $\mathbf{2}$. In case of others, the non-radiative transition rates are at least one order of magnitude larger than the radiative ones, which indicates contribution of the excited singlet state that deactivate by the internal conversion processes.

The complexes studied here can be grouped into two categories. One includes compound 1 that is characterized by rather large Stokes shifts with long radiative lifetimes and the low-energy emissions, and 2-8 that have the high-energy emissions and short fluorescence lifetimes. This suggests that emissions arise from different types of excited states. Presumably, an increase in $\pi$ conjugation length typically results in a red shift of emission and change in corresponding quantum yield. ${ }^{50}$ The spectra roughly follow this rule but some exceptions were also observed. For example, the donating substituent carrying a lone-electron pair as in $\mathbf{1}$ extends the electron conjugation with respect to that in 5. Moreover, this allows efficient polarization of the electronic density upon excitation leading to the largest red-shifted emission. However, the length of conjugation is not the only parameter that influences the emissive state energy of the complexes. The inductive effects or mentioned charge transfer should be also taken into account.

As stated above, distinct red features in the absorption spectrum for $\mathbf{1}$ is ascribed to substantial density change in the $\pi-\pi^{*}$ excited state. These features are dominated by 
excitations in which charge is transferred from donor $\left(4-\mathrm{NMe}_{2}\right)$ to the acceptor $\left(\mathrm{NBF}_{2} \mathrm{O}\right)$ moiety. These observations further support the same interpretation for 4OMe derivative (2) where reorganization of electron density is less efficient than that in 1. From the fluorescence spectra, the emission maximum of $\mathbf{1}$ is red-shifted by 34 $\mathrm{nm}$ compared to that for $\mathbf{2}$. Although the electron donating 4-OMe does not seem to make such a significant effect as $4-\mathrm{NMe}_{2}$, the radiative lifetimes follow the expected trend showing some differences in the quantum yield and fluorescence decay. For $\mathbf{1}$, $\tau_{2}$ is more than twice the value for $\mathbf{2}$, indicating a large long-lived contribution coming from the effect of strong electron donating group. The more electron-rich 1 (versus 5) may slightly weaken the acceptor ability of the $\mathrm{NBF}_{2} \mathrm{O}$ moiety, thus increasing the energy of the transition. Within all 1-8, where $\pi \rightarrow \pi^{*}$ transitions dominate the electronic transitions, the 4-OMe exerts a subtle but measurable effect on fluorescence decay whereas the 4-NMe $\mathrm{N}_{2}$ has significant effect on the excited state properties.

The obtained results suggest that there may be two excited-state conformers for these compounds. One has a structure conducive to the $\pi \rightarrow \pi^{*}$ state being lowest energy in the excited state and gives rise to a short-lived (127-458 ps) $\pi \rightarrow \pi^{*}$ fluorescence. The structure dominates for 1-benzoylmethyleneisoquinoline difluoroborates bearing electron-withdrawing substituents and weak electronreleasing group. Its share of average fluorescence lifetime is in the range 99-93\%. In the case of compounds containing strong electron-donor (4- $\left.\mathrm{NMe}_{2}\right)$ the dominant structure gives an transition associated with substantial charge reorganization and is the source of the much longer-lived emission ( $2.5 \mathrm{~ns})$. While one could expect the systematic changes of properties related to the substituent alteration, here some kind of the sudden drop of properties is observed when passing from 4-Me via 4-OMe to 4$\mathrm{NMe}_{2}$. This suggests the existence of two very different in character fluorescence 
individuals in the latter derivative. A possible scenario is that a conformer with twisted $\mathrm{NMe} 2$ group (or $\mathrm{C}_{6} \mathrm{H}_{4} \mathrm{NMe}_{2}$ ) exists. ${ }^{61-63}$ The excited-state geometry optimization of 4-NMe 2 (at the CAM-B3LYP/6-311++G(d,p) level of theory) revealed an existence of stable conformer with $\mathrm{NMe}_{2}$ group co-planar with phenyl ring. Calculated Stokes shift $(48 \mathrm{~nm})$ was found to be in excellent agreement with experimental value $(46 \mathrm{~nm})$.

In summary, the intensity of the absorption and emission bands increases with increasing electron-donating properties of the substituent in phenyl moiety, and the maxima of the bands are red shifted. A greater disparity in electron-donating ability of the 4-NMe $\mathrm{N}_{2}$ group seems to result in a stronger transition with charge reorganization dominated by the more electron-rich aryl group. However, the $\pi \rightarrow \pi^{*}$ transitions dominate for other 1-benzoylmethyleneisoquinoline difluoroborates.

\section{Comparisons of isoquinolines with quinolines}

For the comparison purposes and in order to gain a further insight into the properties of 1-8 a series of charts were drawn (SI). The properties of 2benzoylmethylenequinoline difluoroborates were used for that purposes. ${ }^{49}$ These comparisons allow to draw the following conclusions for the NMR-derived data: a) the ${ }^{15} \mathrm{~N}$ chemical shift (sensitive to environment ${ }^{64}$ ) is linearly dependent (correlation coefficient $\mathrm{R}=0.99, \mathbf{5}$ and $\mathbf{8}$ excluded) on the substituent constant with similar slope between the series but different intercept (Chart S1), b) the same applies for other chemical shifts as, for example, ${ }^{19} \mathrm{~F}$ data $\left(\mathrm{R}=0.90,1\right.$ excluded from correlation), ${ }^{13} \mathrm{C}$ of carbon no. 1 in isoquinoline $(\mathrm{R}=0.98), \mathrm{CO} \quad(\mathrm{R}=0.95)$ and methine $\mathrm{CH}$ carbon $(\mathrm{R}=0.95)$ atoms, while for the photophysical data it can be concluded: $a)$ the fluorescence quantum yields are, in general, higher for quinoline derivatives than that 
for isoquinolines (Chart $\mathrm{S} 2$ ), $b$ ) the data of the radiative and non-radiative rate constants suggest the non-radiative mechanism dominates (Chart S3) and is responsible for much lower fluorescence quantum yield (Chart S4) in isoquinolines, $c$ ) for the fluorescence lifetimes opposite effect is observed between short and long lived species, id est the correlation with the substituent constant is observed for short lifetime in isoquinolines $(\mathrm{R}=0.93)$ and for the long lifetime for quinolines $(\mathrm{R}=0.97$, Chart S6). The above-mentioned observations lead to the conclusion that variable benzoannulation causes dramatic changes in the photophysical properties of studied molecules. One mechanism that can cause a sudden drop in the fluorescence quantum yield is high non-radiative processes caused by vibrations of the molecular skeleton or by much stronger interaction of the $\mathrm{BF}_{2}$ moiety with the solvent molecules (compare the topology of these derivatives). The detailed studies on these effects are under progress.

\section{Quantum-chemical calculations}

In order to support experimental data, the quantum chemical calculations were performed. In particular, one of the primary aims behind these computations was to analyze the vibrational fine structure of absorption band related to lowest-lying $\pi \rightarrow \pi^{*}$ transition and the associated changes in electronic density. The oscillator strength $(f)$ accompanying this transition is rather large for all studied molecules and is presented in Table 2. It should be highlighted that the largest probability was observed for the one-electron $\mathrm{HOMO} \rightarrow$ LUMO excitation. The frontier orbitals involved in $\pi \rightarrow \pi^{*}$ transition for $\mathbf{1}$ and $\mathbf{5}$ are shown in Table 3 (a complete dataset for all molecules is presented in SI). As seen in accordance with previous conclusions based on 
experimental data, much more significant density change upon excitation is found for 4- $\mathrm{NMe}_{2}$ substituent. In order to put these changes on a quantitative basis, the fragment analysis of frontier molecular orbitals involved in the excitation was performed (cf. section Computational details). It follows from this analysis that the net charge transferred from fragment $\mathbf{B}$ to fragment $\mathbf{A}$ (Fig. 6) upon excitation is $0.47 \mathrm{e}$ and 0.045 e for compound $\mathbf{1}$ and $\mathbf{5}$, respectively.

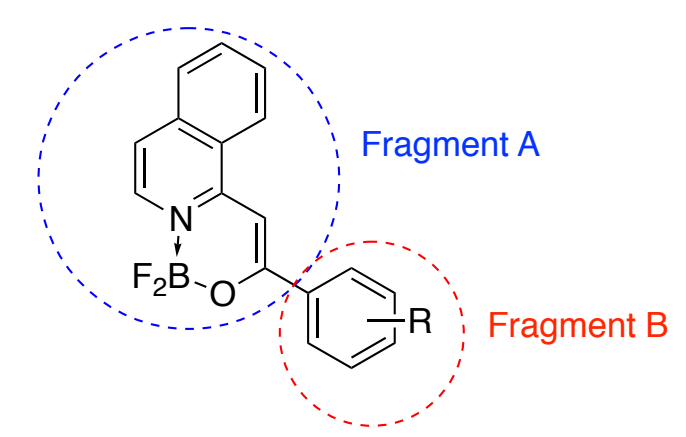

Figure 6. Scheme of the decomposition of molecule into fragments

Although the comparison of computed vertical excitation energy with experimental absorption band maxima still remains the most common route, critical assessment of this approach has already been performed by some authors. ${ }^{65-67}$ In Table 2 there is presented the wavelength corresponding to vertical excitation (computed without zero-point vibrational energy included) and wavelength related to the adiabatic transition (within the IMDHO model the latter value corresponds to the $0-0$ excitation). The results clearly show that the B3LYP functional provides the most accurate estimation of experimental absorption/fluorescence crossing point (referred to as $0-0$ energy). The other two functionals significantly overestimate the $0-0$ energy; the largest deviation from experimental data is found for compound $\mathbf{1}$, characterized by significant charge reorganization upon excitation. Other groups have reported the accurate estimation of the spectroscopic parameters (within TD-DFT scheme) for the cyanine-like molecules (such as BODIPY). ${ }^{68-73}$ 
Table 2. Calculated spectroscopic parameters corresponding to the lowest lying $\left(\pi \rightarrow \pi^{*}\right)$ excited state where $\lambda_{\mathrm{v}}$ and $\lambda_{\text {ad }}$ correspond to vertical and adiabatic transition.

\begin{tabular}{|c|c|c|c|c|c|c|c|c|c|c|}
\hline \multicolumn{11}{|c|}{ Functionals } \\
\hline \multirow{2}{*}{$\begin{array}{c}\text { Substituent } \\
\text { (comp.) }\end{array}$} & \multicolumn{3}{|c|}{ B3LYP } & \multicolumn{3}{|c|}{ CAM-B3LYP } & \multicolumn{3}{|c|}{ PBE0 } & \multirow[t]{2}{*}{$\exp . \lambda_{0-0}[\mathrm{~nm}$} \\
\hline & $\lambda_{v}[\mathrm{~nm}]$ & $\lambda_{\mathrm{ad}}[\mathrm{nm}]$ & $f$ & $\lambda_{\mathrm{v}}[\mathrm{nm}]$ & $\lambda_{\mathrm{ad}}[\mathrm{nm}]$ & $f$ & $\lambda_{\mathrm{v}}[\mathrm{nm}]$ & $\lambda_{\mathrm{ad}}[\mathrm{nm}]$ & $f$ & \\
\hline $4-\mathrm{NMe}_{2}(\mathbf{1})$ & 460 & 477 & 0.985 & 394 & 430 & 1.118 & 422 & 438 & 1.042 & 491 \\
\hline 4-OMe (2) & 412 & 437 & 0.896 & 367 & 411 & 0.955 & 398 & 424 & 0.920 & 442 \\
\hline 4-Me (3) & 401 & 440 & 0.812 & 360 & 395 & 0.858 & 388 & 423 & 0.830 & 438 \\
\hline 3-Me (4) & 396 & 426 & 0.744 & 360 & 397 & 0.817 & 385 & 415 & 0.764 & 431 \\
\hline $\mathrm{H}(\mathbf{5})$ & 395 & 426 & 0.726 & 356 & 390 & 0.781 & 383 & 413 & 0.745 & 429 \\
\hline $4-\operatorname{Br}(6)$ & 400 & 438 & 0.856 & 359 & 397 & 0.889 & 388 & 423 & 0.875 & 432 \\
\hline $3-\operatorname{Br}(7)$ & 395 & 438 & 0.743 & 356 & 393 & 0.798 & 386 & 414 & 0.780 & 430 \\
\hline $4-\mathrm{CF}_{3}(\mathbf{8})$ & 397 & 432 & 0.739 & 355 & 393 & 0.789 & 384 & 418 & 0.745 & 427 \\
\hline
\end{tabular}

In order to gain an insight into the structure of experimentally recorded absorption bands, we have also performed simulation of their vibrational fine structure. The results are presented in Fig. 7 and 8 . In the case of all performed simulations, the homogenous broadening was set to $100 \mathrm{~cm}^{-1}$ and standard deviation of the distribution of 0-0 excitation energies corresponding to inhomogeneous broadening was chosen as $420(\mathbf{6}), 450(\mathbf{2}, \mathbf{3}, \mathbf{5}, \mathbf{7}, \mathbf{8}) 475(4)$ or $500 \mathrm{~cm}^{-1}$ (1) to correctly reproduce the overall absorption band shapes. As can be seen in Fig. 7, among three employed functionals, only CAM-B3LYP satisfactorily predicts the vibrational fine structure of absorption band corresponding to the $\pi \rightarrow \pi^{*}$ transition. Two other functionals incorrectly determine the intensity ratio for major band shoulders. Within the framework of applied model it can be directly related to the displacements between the potential energy surfaces, which are computed based on the excited-state gradients. The differences between the experimental band shape and the profiles simulated using B3LYP and PBE0 functionals may indicate, indirectly, that the latter two functionals have difficulties in predicting excited-state gradients. Thus, CAM-B3LYP functional 
was used to simulate the band shapes for all series of compounds (cf. Fig. 8), which are in good accordance with experimental spectra presented in Fig. 1.

Table 3. Kohn-Sham frontier orbitals determined using B3LYP functional and 6$311++\mathrm{G}(\mathrm{d}, \mathrm{p})$ basis set at the contour surfaces of orbital amplitude $0.04 \mathrm{e} / \mathrm{bohr}^{3}$
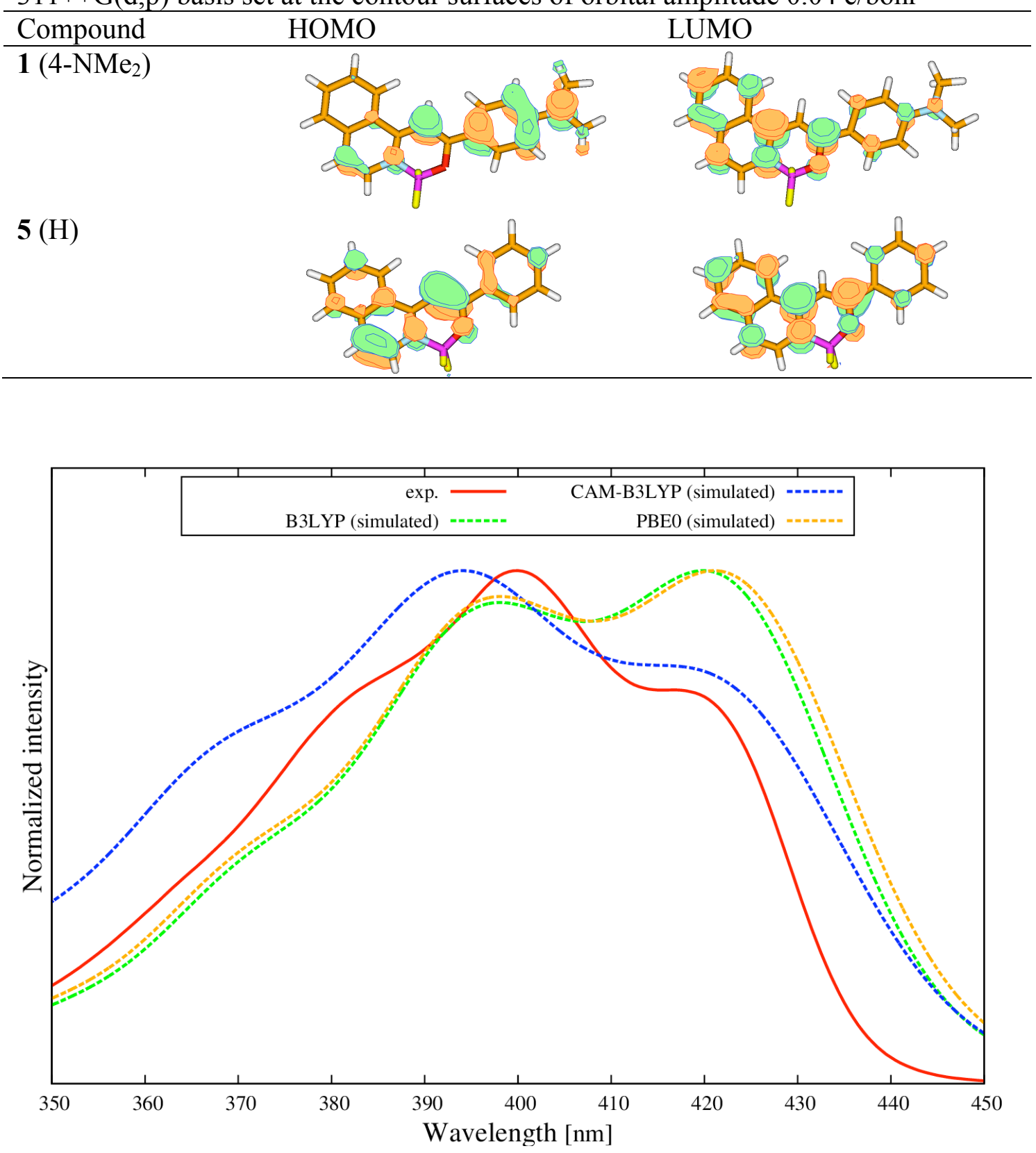

Figure 7. Comparison of experimental and simulated absorption spectra for $\mathrm{R}=\mathrm{H}$ derivative. The spectra were shifted to match the experimental long-wavelength feature 


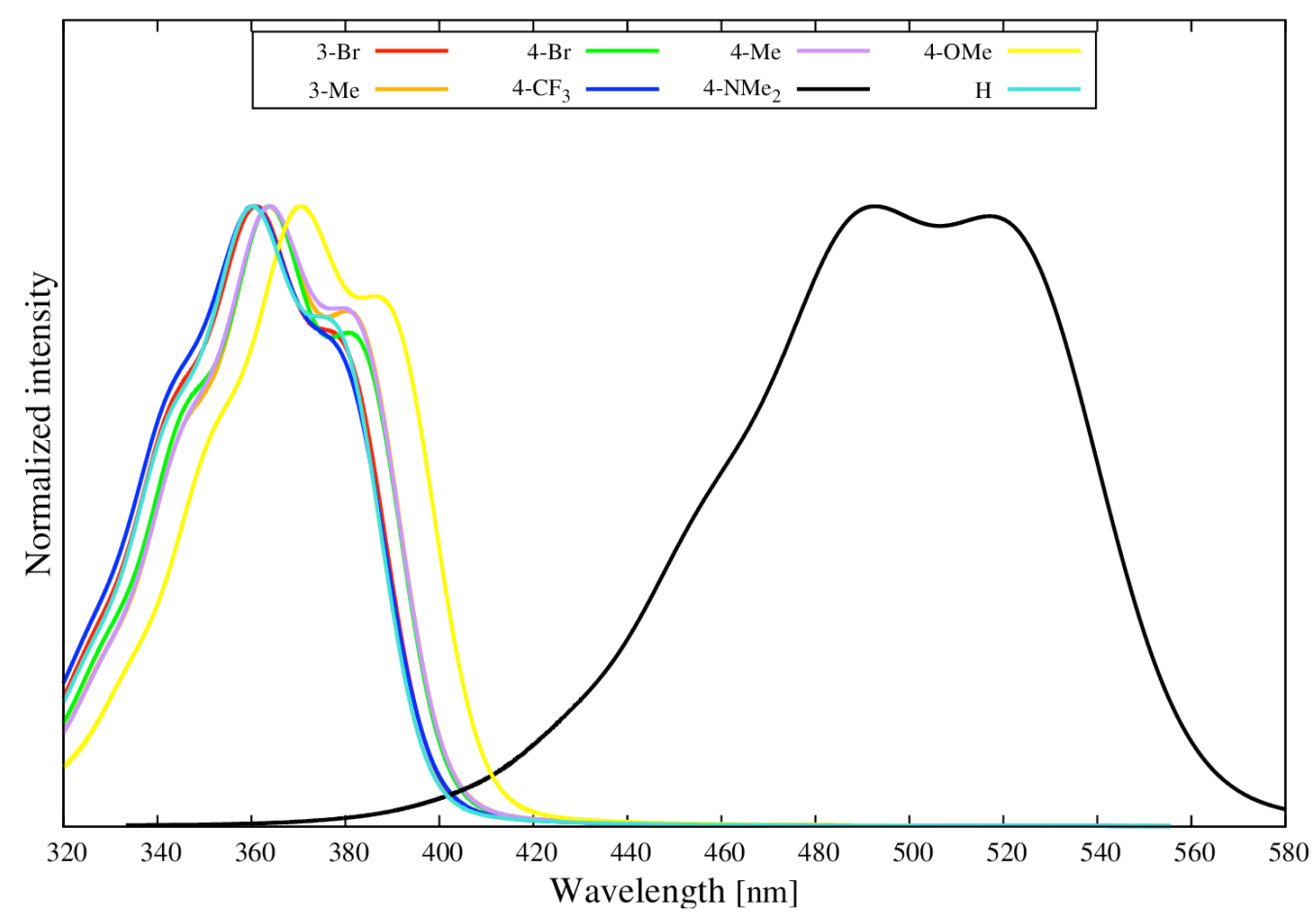

Figure 8. Absorption spectra simulated using CAM-B3LYP functional

\section{Conclusions}

The spectral and computational data show that the absorption and fluorescence properties of substituted 1-benzoylmethyleneisoquinoline difluoroborates are similar to those in quinoline derivatives while some small spectral shifts are noticed. The most dramatic differences between quinoline and isoquinoline derivatives are within their fluorescence quantum yield, which decreases quickly when going from strong to weak electron donating substituent. This shows that isoquinolines are less attractive for their use as fluorescent probes. Moreover, this also shows that a special care should be paid not only to the substituent applied, degree of $\pi$-electron conjugation, benzoannulation but also to the way the benzoannulation takes place. This clearly influences the synthetic procedures that would lead to materials with desired properties. The correlations of the NMR chemical shifts with substituent constants are similar as in quinolines making the substituent effect in the ground state similar 
between these series It has been found that only CAM-B3LYP functionals yields the correct absorption band shape for studied molecules.

\section{Experimental}

The 1-benzoylmethyleneisoquinoline difluoroborates were synthesized as before (ketone synthesis ${ }^{51}$; complexation ${ }^{22}$ ). The same applies for visible ${ }^{49}$ and $\mathrm{NMR}^{52}$ spectral measurements. Electronic structure calculations were performed using the Kohn-Sham formulation of density functional theory. In order to take into account the conditions of experimental measurements, the calculation were carried out in the presence of the solvent, using the linear response polarizable continuum model $\left(\right.$ LR-PCM $\left.{ }^{74}\right)$. Comparison of linear LR-PCM with more accurate corrected LRPCM can be found in recent paper by Chibani et al.. ${ }^{75}$ Optimization of the ground state geometry was carried out using three different exchange-correlation functionals: B3LYP, CAM-B3LYP, and PBE0. Vertical excitation energies were computed employing the time-dependent density functional theory. For all quantum-chemical calculations 6-311++G(d,p) basis set was used. All electronic structure calculations were performed using Gaussian 2009 D01 program. ${ }^{76}$ Additionally, in order to simulate the vibrational structure of the absorption spectra, orca_asa program was used (the part of ORCA package). ${ }^{77}$ Simulations of the absorption bands, interrelated with transitions to the $\left(\pi-\pi^{*}\right)$ excited state, were performed using Independent Mode Displaced Harmonic Oscillator (IMDHO) approximation. In the case of ground electronic state, the entire set of normal modes of vibration was included in simulations. Dimensionless normal coordinate displacements $\left(\Delta_{\mathrm{Q}, \mathrm{k}}\right)$ for excited-state with respect to the ground state equilibrium geometry were calculated using custom software as follows: 


$$
\Delta_{Q, k}=-\frac{1}{\omega_{e k}^{2}}\left[\frac{\partial E}{\partial Q_{k}}\right]_{Q=0}
$$

where $\left[\frac{\partial E}{\partial Q_{k}}\right]_{Q=0}$ corresponds to excited-state potential energy gradient along the $k$-th normal mode at the ground-state geometry. The energy of adiabatic transition was computed according to the following formula:

$$
\Delta E_{a d}=\Delta E_{v}-\sum_{k} \frac{\omega_{k}}{2} \Delta_{k}^{2}
$$

In this study we also present a fragment analysis of the molecular orbitals. It is carried out under the assumption that one can divide molecular structure into $N$ fragments. The electronic density may then be decomposed and described by means of atomic orbitals centred on nuclei corresponding to the fragments. Fragment contribution is computed as $^{78}$ :

$$
C_{\text {frag }}=\sum_{j}^{n_{\text {frag }}} c_{j}^{2}+\sum_{j}^{n_{\text {frag }}} \sum_{i<j}^{n_{\text {frag }}} 2 c_{i} c_{j} S_{i j}
$$

where $i$ and $j$ run over the $n_{\text {frag }}$ basis set atomic orbitals, $c_{i}$ is the coefficient by which the basis function enters the molecular orbital and $S_{i j}$ is the basis set overlap matrix element.

\section{Compounds Characterization}

All compounds were obtained ${ }^{22}$ as described for quinoline derivatives. ${ }^{49}$ The reaction yields (after purification) varied between 35 and 45\%. The typical procedure was as follows: to the magnetically stirred solution (nitrogen atmosphere) of substituted 1benzoylmethyleneisoquinoline $(1 \mathrm{~g})$ in dry chloroform $(15-20 \mathrm{ml})$ and Nethyldiisopropylamine (two equivalents) $\mathrm{BF}_{3}$ etherate (two equivalents) was added. The solution was stirred overnight at room temperature and then concentrated $\mathrm{Na}_{2} \mathrm{CO}_{3}$ 
water solution $(20 \mathrm{ml})$ was added slowly to the mixture. The organic fraction was separated, water layer extracted with chloroform (two times using ca. 20-30 ml), dryed $\left(\mathrm{Na}_{2} \mathrm{SO}_{4}\right)$ and evaporated under reduced pressure. Residual solids were purified by flash chromatography $\left(\mathrm{SiO}_{2}\right)$ using acetonitrile (1) or DCM (2-8) as an eluent. 1-(4-Dimethylamino)benzoylmethyleneisoquinoline difluoroborate (1) $0.52 \mathrm{~g}$ (44.6\%). ${ }^{1} \mathrm{H}$ NMR (DMSO- $d_{6}$ from TMS) $\delta: 8.92\left(\mathrm{~d}, 1 \mathrm{H},{ }^{3} \mathrm{~J}_{\mathrm{H}, \mathrm{H}}=8.3 \mathrm{~Hz}\right), 8.07(\mathrm{~d}, 2 \mathrm{H}$, $\left.{ }^{3} \mathrm{~J}_{\mathrm{H}, \mathrm{H}}=9.0 \mathrm{~Hz}\right), 8.02-7.97(\mathrm{~m}, 2 \mathrm{H}), 7.83(\mathrm{t}, 1 \mathrm{H}), 7.68\left(\mathrm{~d}, 1 \mathrm{H},{ }^{3} \mathrm{~J}_{\mathrm{H}, \mathrm{H}}=6.8 \mathrm{~Hz}\right), 7.46(\mathrm{~s}, 1 \mathrm{H})$, $6.82\left(\mathrm{~d}, 2 \mathrm{H},{ }^{3} \mathrm{~J}_{\mathrm{H}, \mathrm{H}}=9.0 \mathrm{~Hz}\right), 3.06(\mathrm{~s}, 6 \mathrm{H}) .{ }^{11} \mathrm{~B} \mathrm{NMR}\left(\mathrm{DMSO}-d_{6}\right.$ from $\left.\mathrm{BF}_{3} \cdot \mathrm{Et}_{2} \mathrm{O}\right) \delta$ : $1.588(\mathrm{t}),{ }^{13} \mathrm{C}$ NMR (DMSO- $d_{6}$ from TMS) $\delta: 165.8,152.9,152.8,136.5,134.3,131.4$, $129.5,129.2,127.8,127.3,123.8,120.7,117.8,111.9,87.4$, ca. 40 (overlapped with solvent signal), ${ }^{15} \mathrm{~N}\left(\mathrm{DMSO}-d_{6}\right.$ from $\left.\mathrm{MeNO}_{2}\right) \delta:-196.3,{ }^{19} \mathrm{~F}$ NMR (DMSO- $d_{6}$ from

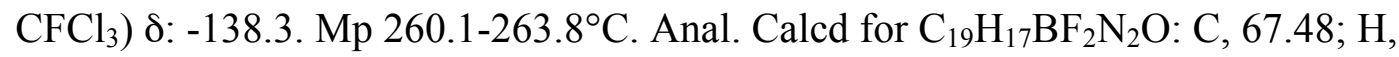
5.07; N, 8.28. Found: C, 67.41; H, 5.11; N, 8.20.

1-(4-Methoxy)benzoylmethyleneisoquinoline difluoroborate (2) $0.41 \mathrm{~g}(35.0 \%)$. ${ }^{1} \mathrm{H}$ NMR $\left(\mathrm{CDCl}_{3}\right.$ from TMS $) \delta: 8.40\left(\mathrm{~d}, 1 \mathrm{H},{ }^{3} \mathrm{~J}_{\mathrm{H}, \mathrm{H}}=8.3 \mathrm{~Hz}\right), 8.17\left(\mathrm{~d}, 1 \mathrm{H},{ }^{3} \mathrm{~J}_{\mathrm{H}, \mathrm{H}}=5.4 \mathrm{~Hz}\right)$, $8.04\left(\mathrm{~d}, 2 \mathrm{H},{ }^{3} \mathrm{~J}_{\mathrm{H}, \mathrm{H}}=8.9 \mathrm{~Hz}\right), 7.87(\mathrm{t}, 1 \mathrm{H}), 7.84(\mathrm{t}, 1 \mathrm{H}), 7.74(\mathrm{t}, 1 \mathrm{H}), 7.47(\mathrm{~d}, 1 \mathrm{H}$, $\left.{ }^{3} \mathrm{~J}_{\mathrm{H}, \mathrm{H}}=6.8 \mathrm{~Hz}\right), 7.08(\mathrm{~s}, 1 \mathrm{H}), 6.98\left(\mathrm{~d}, 2 \mathrm{H},{ }^{3} \mathrm{~J}_{\mathrm{H}, \mathrm{H}}=8.9 \mathrm{~Hz}\right), 3.89(\mathrm{~s}, 3 \mathrm{H}) .{ }^{11} \mathrm{~B}$ NMR $(\mathrm{CDCl} 3$ from $\left.\mathrm{BF}_{3} \cdot \mathrm{Et}_{2} \mathrm{O}\right) \delta: 1.762(\mathrm{t}),{ }^{13} \mathrm{C} \mathrm{NMR} \delta: 165.9,162.5,152.7,136.6,133.4,131.6$, $128.9,128.7,127.5,126.8,125.6,123.8,117.8,114.0,88.0,55.5 .{ }^{15} \mathrm{~N} \mathrm{NMR}\left(\mathrm{CDCl}_{3}\right.$

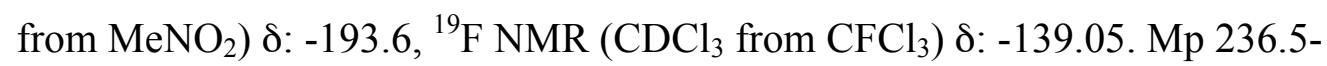
238. $7^{\circ} \mathrm{C}$. Anal. Calcd for $\mathrm{C}_{18} \mathrm{H}_{14} \mathrm{BF}_{2} \mathrm{NO}_{2}$ : C, 66.50; H, 4.34; N, 4.31. Found: C, 66.39; $\mathrm{H}, 4.52 ; \mathrm{N}, 4.23$.

1-(4-Methyl)benzoylmethyleneisoquinoline difluoroborate (3) 0.49g (41.4\%).

${ }^{1} \mathrm{H}$ NMR $\left(\mathrm{CDCl}_{3}\right.$ from TMS) $\delta: 8.42\left(\mathrm{~d}, 1 \mathrm{H},{ }^{3} \mathrm{~J}_{\mathrm{H}, \mathrm{H}}=8.4 \mathrm{~Hz}\right), 8.21\left(\mathrm{~d}, 1 \mathrm{H},{ }^{3} \mathrm{~J}_{\mathrm{H}, \mathrm{H}}=5.6 \mathrm{~Hz}\right)$, $7.98\left(\mathrm{~d}, 2 \mathrm{H},{ }^{3} \mathrm{~J}_{\mathrm{H}, \mathrm{H}}=8.4 \mathrm{~Hz}\right), 7.89(\mathrm{t}, 1 \mathrm{H}), 7.86(\mathrm{t}, 1 \mathrm{H}), 7.76(\mathrm{t}, 1 \mathrm{H}), 7.51(\mathrm{~d}, 1 \mathrm{H}$, 
$\left.{ }^{3} \mathrm{~J}_{\mathrm{H}, \mathrm{H}}=6.8 \mathrm{~Hz}\right), 7.30\left(\mathrm{~d}, 2 \mathrm{H},{ }^{3} \mathrm{~J}_{\mathrm{H}, \mathrm{H}}=8.4 \mathrm{~Hz}\right), 7.15(\mathrm{~s}, 1 \mathrm{H}), 2.45(\mathrm{~s}, 3 \mathrm{H}) .{ }^{11} \mathrm{~B} \mathrm{NMR}(\mathrm{CDCl} 3$ from $\left.\mathrm{BF}_{3} \cdot \mathrm{Et}_{2} \mathrm{O}\right) \delta: 1.787(\mathrm{t}),{ }^{13} \mathrm{C} \mathrm{NMR} \delta: 166.1,152.7,142.1,136.5,133.4,131.6$, $131.5,129.3,128.8,127.5,127.0,125.7,123.8,118.1,88.8,21.5 .{ }^{15} \mathrm{~N} \mathrm{NMR}\left(\mathrm{CDCl}_{3}\right.$ from $\left.\mathrm{MeNO}_{2}\right) \delta:-192.5 .{ }^{19} \mathrm{~F} \mathrm{NMR}\left(\mathrm{CDCl}_{3}\right.$ from $\left.\mathrm{CFCl}_{3}\right) \delta:-138.7 . \mathrm{Mp} 231.2-233.5^{\circ} \mathrm{C}$. Anal. Calcd for $\mathrm{C}_{18} \mathrm{H}_{14} \mathrm{BF}_{2} \mathrm{NO}$ : C, 69.94; H, 4.56; N, 4.53. Found: C, 69.75; H, 4.71; $\mathrm{N}, 4.44$.

1-(3-Methyl)benzoylmethyleneisoquinoline difluoroborate (4) $0.51 \mathrm{~g}(43.1 \%)$.

${ }^{1} \mathrm{H}$ NMR $\left(\mathrm{CDCl}_{3}\right.$ from TMS $) \delta: 8.43\left(\mathrm{~d}, 1 \mathrm{H},{ }^{3} \mathrm{~J}_{\mathrm{H}, \mathrm{H}}=8.7 \mathrm{~Hz}\right), 8.21\left(\mathrm{~d}, 1 \mathrm{H},{ }^{3} \mathrm{~J}_{\mathrm{H}, \mathrm{H}}=6.8 \mathrm{~Hz}\right)$, 7.90-7.84 (overlapped signals, 4H), $7.76(\mathrm{t}, 1 \mathrm{H}), 7.52\left(\mathrm{~d}, 1 \mathrm{H},{ }^{3} \mathrm{~J}_{\mathrm{H}, \mathrm{H}}=6.8 \mathrm{~Hz}\right), 7.37(\mathrm{t}$, 1H), $7.31\left(\mathrm{~d}, 1 \mathrm{H},{ }^{3} \mathrm{~J}_{\mathrm{H}, \mathrm{H}}=7.6 \mathrm{~Hz}\right), 7.16(\mathrm{~s}, 1 \mathrm{H}), 2.45(\mathrm{~s}, 3 \mathrm{H}) .{ }^{11} \mathrm{~B}$ NMR (CDCl3 from $\left.\mathrm{BF}_{3} \cdot \mathrm{Et}_{2} \mathrm{O}\right) \delta: 1.800(\mathrm{t}),{ }^{13} \mathrm{C} \mathrm{NMR} \delta: 166.1,152.6,138.4,136.6,134.3,133.5,132.3$, $131.7,128.9,128.5,127.6,127.5,125.7,124.1,123.8,118.4,89.3,21.4 .{ }^{15} \mathrm{~N}$ NMR

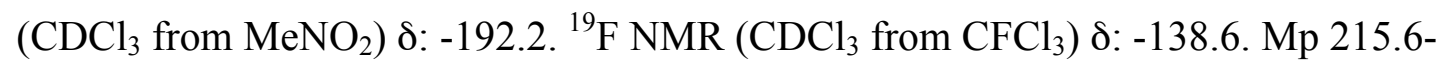
218.4 ${ }^{\circ}$ C. Anal. Calcd for $\mathrm{C}_{18} \mathrm{H}_{14} \mathrm{BF}_{2} \mathrm{NO}$ : C, 69.94; H, 4.56; N, 4.53. Found: C, 69.81; H, 4.78; N, 4.49.

1-Benzoylmethyleneisoquinoline difluoroborate (5) 0.49g (41.1\%). ${ }^{1} \mathrm{H}$ NMR $\left(\mathrm{CDCl}_{3}\right.$ from TMS $) \delta: 8.42\left(\mathrm{~d}, 1 \mathrm{H}, \mathrm{J}_{\mathrm{H}, \mathrm{H}}=8.5 \mathrm{~Hz}\right), 8.22\left(\mathrm{~d}, 1 \mathrm{H},{ }^{3} \mathrm{~J}_{\mathrm{H}, \mathrm{H}}=6.1 \mathrm{~Hz}\right), 8.07(\mathrm{~d}$, $\left.2 \mathrm{H},{ }^{3} \mathrm{~J}_{\mathrm{H}, \mathrm{H}}=8.2 \mathrm{~Hz}\right), 7.89(\mathrm{t}, 1 \mathrm{H}), 7.86(\mathrm{t}, 1 \mathrm{H}), 7.76(\mathrm{t}, 1 \mathrm{H}), 7.53\left(\mathrm{~d}, 1 \mathrm{H},{ }^{3} \mathrm{~J}_{\mathrm{H}, \mathrm{H}}=6.8 \mathrm{~Hz}\right)$, 7.51-7.45 (m, 3H), $7.17(\mathrm{~s}, 1 \mathrm{H}) .{ }^{11} \mathrm{~B} \mathrm{NMR}\left(\mathrm{CDCl} 3\right.$ from $\left.\mathrm{BF}_{3} \cdot \mathrm{Et}_{2} \mathrm{O}\right) \delta: 1.805(\mathrm{t}),{ }^{13} \mathrm{C}$ NMR $\delta: 165.9,152.6,136.6,134.4,133.5,131.7,131.5,128.9,128.6,127.5,126.9$, 125.7, 123.8, 118.5, 89.3. ${ }^{15} \mathrm{~N}$ NMR $\left(\mathrm{CDCl}_{3}\right.$ from $\left.\mathrm{MeNO}_{2}\right) \delta:-195.7 .{ }^{19} \mathrm{~F} \mathrm{NMR}$

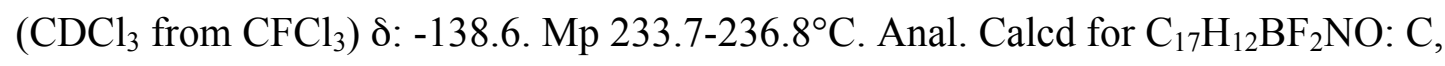
69.19; H, 4.10; N, 4.75. Found: C, 69.13; H, 4.06; N, 4.70. 1-(4-Bromo)benzoylmethyleneisoquinoline difluoroborate (6) $0.50 \mathrm{~g}(43.6 \%)$. ${ }^{1} \mathrm{H}$ NMR $\left(\mathrm{CDCl}_{3}\right.$ from TMS) $\delta: 8.42\left(\mathrm{~d}, 1 \mathrm{H},{ }^{3} \mathrm{~J}_{\mathrm{H}, \mathrm{H}}=8.4 \mathrm{~Hz}\right), 8.24\left(\mathrm{~d}, 1 \mathrm{H},{ }^{3} \mathrm{~J}_{\mathrm{H}, \mathrm{H}}=6.8 \mathrm{~Hz}\right)$, 
7.94-7.87 (m, 4H), $7.80(\mathrm{t}, 1 \mathrm{H}), 7.60\left(\mathrm{~d}, 2 \mathrm{H},{ }^{3} \mathrm{~J}_{\mathrm{H}, \mathrm{H}}=8.5 \mathrm{~Hz}\right), 7.58\left(\mathrm{~d}, 1 \mathrm{H},{ }^{3} \mathrm{~J}_{\mathrm{H}, \mathrm{H}}=6.6 \mathrm{~Hz}\right)$,

$7.16(\mathrm{~s}, 1 \mathrm{H}) .{ }^{11} \mathrm{~B} \mathrm{NMR}\left(\mathrm{CDCl} 3\right.$ from $\left.\mathrm{BF}_{3} \cdot \mathrm{Et}_{2} \mathrm{O}\right) \delta: 1.750(\mathrm{t}),{ }^{13} \mathrm{C} \mathrm{NMR} \delta: 164.5,152.3$, $136.7,133.7,133.3,131.9,131.7,129.1,128.4,127.6,126.1,125.6,123.8,118.8$ 89.5. ${ }^{15} \mathrm{~N} \mathrm{NMR}\left(\mathrm{CDCl}_{3}\right.$ from $\left.\mathrm{MeNO}_{2}\right) \delta:-190.4 .{ }^{19} \mathrm{~F} \mathrm{NMR}\left(\mathrm{CDCl}_{3}\right.$ from $\left.\mathrm{CFCl}_{3}\right) \delta$ : 138.5. Mp 231.8-234. $9^{\circ} \mathrm{C}$. Anal. Calcd for $\mathrm{C}_{17} \mathrm{H}_{11} \mathrm{BBrF}_{2} \mathrm{NO}: \mathrm{C}, 54.60 ; \mathrm{H}, 2.96$; , 3.75. Found: C, 54.53; H, 3.01; N, 3.67.

1-(3-Bromo)benzoylmethyleneisoquinoline difluoroborate (7) $0.44 \mathrm{~g}$ (38.4\%).

${ }^{1} \mathrm{H}$ NMR $\left(\mathrm{CDCl}_{3}\right.$ from TMS $) \delta: 8.44\left(\mathrm{~d}, 1 \mathrm{H},{ }^{3} \mathrm{~J}_{\mathrm{H}, \mathrm{H}}=8.3 \mathrm{~Hz}\right), 8.25\left(\mathrm{~d}, 1 \mathrm{H},{ }^{3} \mathrm{~J}_{\mathrm{H}, \mathrm{H}}=6.3 \mathrm{~Hz}\right)$, $8.20(\mathrm{~m}, 1 \mathrm{H}), 7.99\left(\mathrm{~d}, 1 \mathrm{H},{ }^{3} \mathrm{~J}_{\mathrm{H}, \mathrm{H}}=8.0 \mathrm{~Hz}\right), 7.94-7.86(\mathrm{~m}, 2 \mathrm{H}), 7.80(\mathrm{t}, 1 \mathrm{H}), 7.63(\mathrm{~d}, 1 \mathrm{H}$, $\left.{ }^{3} \mathrm{~J}_{\mathrm{H}, \mathrm{H}}=8.0 \mathrm{~Hz}\right), 7.59\left(\mathrm{~d}, 1 \mathrm{H},{ }^{3} \mathrm{~J}_{\mathrm{H}, \mathrm{H}}=6.8 \mathrm{~Hz}\right), 7.36(\mathrm{t}, 1 \mathrm{H}), 7.15(\mathrm{~s}, 1 \mathrm{H}) .{ }^{11} \mathrm{~B}$ NMR $(\mathrm{CDCl} 3$ from $\left.\mathrm{BF}_{3} \cdot \mathrm{Et}_{2} \mathrm{O}\right) \delta: 1.748(\mathrm{t}),{ }^{13} \mathrm{C}$ NMR $\delta: 164.0,152.3,136.7,136.4,134.2,133.7$, $131.8,130.1,129.8,129.1,127.6,125.7,125.5,123.8,122.9,119.1,90.0 .{ }^{15} \mathrm{~N} N M R$

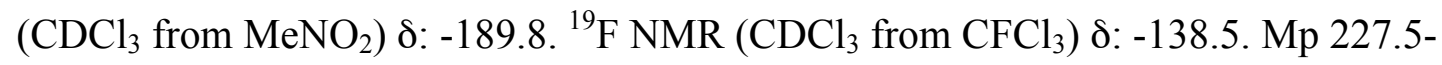
229. $2^{\circ}$ C. Anal. Calcd for $\mathrm{C}_{17} \mathrm{H}_{11} \mathrm{BBrF}_{2} \mathrm{NO}$ : C, 54.60; H, 2.96; N, 3.75. Found: C, 54.48; H, 3.09; N, 3.68.

1-(4-Trifluoromethyl)benzoylmethyleneisoquinoline difluoroborate (8) 0.48g

(41.7\%). ${ }^{1} \mathrm{H}$ NMR $\left(\mathrm{CDCl}_{3}\right.$ from TMS) $\delta: 8.44\left(\mathrm{~d}, 1 \mathrm{H},{ }^{3} \mathrm{~J}_{\mathrm{H}, \mathrm{H}}=8.5 \mathrm{~Hz}\right), 8.26(\mathrm{~d}, 1 \mathrm{H}$, $\left.{ }^{3} \mathrm{~J}_{\mathrm{H}, \mathrm{H}}=6.6 \mathrm{~Hz}\right), 8.12\left(\mathrm{~d}, 2 \mathrm{H},{ }^{3} \mathrm{~J}_{\mathrm{H}, \mathrm{H}}=8.3 \mathrm{~Hz}\right), 7.93(\mathrm{t}, 1 \mathrm{H}), 7.88\left(\mathrm{~d}, 1 \mathrm{H},{ }^{3} \mathrm{~J}_{\mathrm{H}, \mathrm{H}}=7.5 \mathrm{~Hz}\right), 7.81$ $(\mathrm{t}, 1 \mathrm{H}), 7.69\left(\mathrm{~d}, 2 \mathrm{H},{ }^{3} \mathrm{~J}_{\mathrm{H}, \mathrm{H}}=8.3 \mathrm{~Hz}\right), 7.59\left(\mathrm{~d}, 1 \mathrm{H},{ }^{3} \mathrm{~J}_{\mathrm{H}, \mathrm{H}}=6.6 \mathrm{~Hz}\right), 7.22(\mathrm{~s}, 1 \mathrm{H}) .{ }^{11} \mathrm{~B} \mathrm{NMR}$ $\left(\mathrm{CDCl} 3\right.$ from $\left.\mathrm{BF}_{3} \cdot \mathrm{Et}_{2} \mathrm{O}\right) \delta: 1.770(\mathrm{t}),{ }^{13} \mathrm{C} \mathrm{NMR} \delta: 163.6,152.1,137.6,136.7,133.8$ $132.7,131.7,129.2,127.6,127.0,125.7,125.5,125.14,123.8,122.4,119.4,90.6 .{ }^{15} \mathrm{~N}$

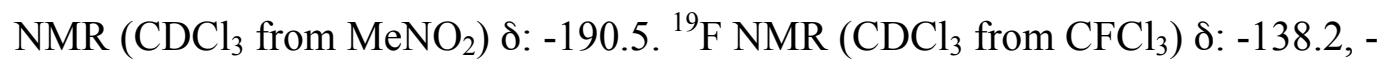
62.9. Mp 230.9-234. $2^{\circ}$ C. Anal. Calcd for $\mathrm{C}_{18} \mathrm{H}_{11} \mathrm{BF}_{5} \mathrm{NO}$ : C, 59.54; H, 3.05; N, 3.86 . Found: C, 59.45; H, 3.14; N, 3.81. 


\section{Supporting Information}

NMR spectra, correlation and comparison charts, fluorescence decay spectra, computational results and Cartesian coordinates. This material is available free of charge via the Internet at http://pubs.acs.org.

\section{Acknowledgments}

Financial support from the National Science Centre (Grant No. 2013/09/B/ST5/03550) is gratefully acknowledged. This research was supported by PL-Grid Infrastructure and the Wroclaw Center for Networking and Supercomputing. R.Z. is a Wenner-Gren Foundations scholar.

\section{References}

(1) Loudet, A.; Burgess, K. Chem. Rev. 2007, 107, 4891.

(2) Boens, N.; Leen, V.; Dehaen, W. Chem. Soc. Rev. 2012, 41, 1130.

(3) Kamkaew, A.; Lim, S. H.; Lee, H. B.; Kiew, L. V.; Chung, L. Y.; Burgess, K. Chem. Soc. Rev. 2013, 42, 77.

(4) Nepomnyashchii, A. B.; Bard, A. J. Acc. Chem. Res. 2012, 45, 1844.

(5) Frath, D.; Massue, J.; Ulrich, G.; Ziessel, R. Angew. Chem. Int. Ed. 2014, 53, 2290.

(6) Jacquemin, D.; Chibani, S.; Le Guennic, B.; Mennucci, B. J. Phys. Chem. A 2014, 118, 5343.

(7) Chibani, S.; Laurent, A. D.; Le Guennic, B.; Jacquemin, D. J. Chem. Theory Comput. 2014, 10, 4574.

(8) Laurent, A. D.; Adamo, C.; Jacquemin, D. Phys. Chem. Chem. Phys. 2014, 16, 14334.

(9) Nie, S.; Chiu, D. T.; Zare, R. N. Anal. Chem. 1995, 67, 2849.

(10) Ozdemir, T.; Sozmen, F.; Mamur, S.; Tekinay, T.; Akkaya, E. U. Chem. Commun. 2014, 50, 5455.

(11) Cao, X.; Lin, W.; Yu, Q.; Wang, J. Org. Lett. 2011, 13, 6098.

(12) Suzuki, S.; Kozaki, M.; Nozaki, K.; Okada, K. J. Photochem.

Photobiol. C: Photochem. Rev. 2011, 12, 269.

(13) Lin, H.-Y.; Huang, W.-C.; Chen, Y.-C.; Chou, H.-H.; Hsu, C.-Y.; Lin, J. T.; Lin, H.-W. Chem. Commun. 2012, 48, 8913.

(14) Ooyama, Y.; Hagiwara, Y.; Mizumo, T.; Harima, Y.; Ohshita, J. RSC Adv. 2013, 3, 18099 .

(15) Kubota, Y.; Ozaki, Y.; Funabiki, K.; Matsui, M. J. Org. Chem. 2013, $78,7058$. 
(16) Kubota, Y.; Sakuma, Y.; Funabiki, K.; Matsui, M. J. Phys. Chem. A 2014, 118,8717 .

(17) Kubota, Y.; Hara, H.; Tanaka, S.; Funabiki, K.; Matsui, M. Org. Lett. 2011, 13, 6544 .

(18) Graser, M.; Kopacka, H.; Wurst, K.; Ruetz, M.; Kreutz, C. R.; Müller, T.; Hirtenlehner, C.; Monkowius, U.; Knör, G.; Bildstein, B. Inorg. Chim. Acta 2013, $405,116$.

(19) Xia, M.; Wu, B.; Xiang, G. J. Fluor. Chem. 2008, 129, 402.

(20) Yan, W.; Wan, X.; Chen, Y. J. Mol. Struct. 2010, 968, 85.

(21) Tokoro, Y.; Nagai, A.; Chujo, Y. Macromolecules 2010, 43, 6229.

(22) Zhou, Y.; Xiao, Y.; Li, D.; Fu, M.; Qian, X. J. Org. Chem. 2008, 73,

1571.

(23) Díaz-Moscoso, A.; Emond, E.; Hughes, D. L.; Tizzard, G. J.; Coles, S. J.; Cammidge, A. N. J. Org. Chem. 2014, 79, 8932.

(24) Li, H.-J.; Fu, W.-F.; Li, L.; Gan, X.; Mu, W.-H.; Chen, W.-Q.; Duan, X.-M.; Song, H.-B. Org. Lett. 2010, 12, 2924.

(25) Fischer, G. M.; Daltrozzo, E.; Zumbusch, A. Angew. Chem. Int. Ed. 2011, 50, 1406.

(26) Nagai, A.; Kokado, K.; Nagata, Y.; Arita, M.; Chujo, Y. J. Org. Chem. 2008, 73, 8605 .

(27) Samonina-Kosicka, J.; DeRosa, C. A.; Morris, W. A.; Fan, Z.; Fraser, C. L. Macromolecules 2014, 47, 3736.

(28) Poon, C.-T.; Lam, W. H.; Wong, H.-L.; Yam, V. W.-W. J. Am. Chem. Soc. 2010, 132, 13992.

3092 .

(29) Zhang, G.; St. Clair, T. L.; Fraser, C. L. Macromolecules 2009, 42,

(30) Frath, D.; Azizi, S.; Ulrich, G.; Ziessel, R. Org. Lett. 2012, 14, 4774.

(31) Frath, D.; Azizi, S. b.; Ulrich, G.; Retailleau, P.; Ziessel, R. Org. Lett. 2011, 13, 3414.

(32) Yu, C.; Jiao, L.; Zhang, P.; Feng, Z.; Cheng, C.; Wei, Y.; Mu, X.; Hao, E. Org. Lett. 2014, 16, 3048.

(33) Suresh, D.; Gomes, C. S. B.; Gomes, P. T.; Di Paolo, R. E.; Macanita, A. L.; Calhorda, M. J.; Charas, A.; Morgado, J.; Teresa Duarte, M. J. Chem. Soc. Dalton. Trans. 2012, 41, 8502.

(34) Kertesz, M.; Choi, C. H.; Yang, S. Chem. Rev. 2005, 105, 3448.

(35) Sobczyk, L.; Grabowski, S. J.; Krygowski, T. M. Chem. Rev. 2005, $105,3513$.

(36) Raczyńska, E. D.; Kosińska, W.; Ośmiałowski, B.; Gawinecki, R. Chem. Rev. 2005, 105, 3561.

(37) Cyrański, M. K. Chem. Rev. 2005, 105, 3773.

(38) Ortí, E.; Viruela, R.; Viruela, P. M. J. Phys. Chem. 1996, 100, 6138.

(39) Soldatova, A. V.; Kim, J.; Peng, X.; Rosa, A.; Ricciardi, G.; Kenney, M. E.; Rodgers, M. A. J. Inorg. Chem. 2007, 46, 2080.

(40) Kolehmainen, E.; Ośmiałowski, B.; Krygowski, T. M.; Kauppinen, R.; Nissinen, M.; Gawinecki, R. J. Chem. Soc. Perkin Trans. 2 2000, 1259.

(41) Kolehmainen, E.; Ośmiałowski, B.; Nissinen, M.; Kauppinen, R.;

Gawinecki, R. J. Chem. Soc. Perkin Trans. 2 2000, 2185.

(42) Ośmiałowski, B.; Kolehmainen, E.; Nissinen, M.; Krygowski, T. M.;

Gawinecki, R. J. Org. Chem. 2002, 67, 3339. 
(43) Krygowski, T. M.; Zachara, J. E.; Ośmiałowski, B.; Gawinecki, R. J. Org. Chem. 2006, 71, 7678.

(44) Min, J.; Ameri, T.; Gresser, R.; Lorenz-Rothe, M.; Baran, D.; Troeger, A.; Sgobba, V.; Leo, K.; Riede, M.; Guldi, D. M.; Brabec, C. J. ACS Appl. Mater. Interfaces 2013, 5, 5609.

(45) Gresser, R.; Hummert, M.; Hartmann, H.; Leo, K.; Riede, M. Chem. Eur. J. 2011, 17, 2939.

1217.

(46) Ni, Y.; Zeng, W.; Huang, K.-W.; Wu, J. Chem. Commun. 2013, 49,

(47) Mueller, T.; Gresser, R.; Leo, K.; Riede, M. Sol. Energ. Mat. Sol. C. 2012, 99, 176.

(48) Kubo, Y.; Minowa, Y.; Shoda, T.; Takeshita, K. Tetrahedron Lett. 2010, 51, 1600.

(49) Zakrzewska, A.; Zaleśny, R.; Kolehmainen, E.; Ośmiałowski, B.; Jędrzejewska, B.; Ågren, H.; Pietrzak, M. Dyes Pigments 2013, 99, 957.

(50) Yamaguchi, Y.; Matsubara, Y.; Ochi, T.; Wakamiya, T.; Yoshida, Z.-i. J. Am. Chem. Soc. 2008, 130, 13867.

(51) Goldberg, N. N.; Barkley, L. B.; Levine, R. J. Am. Chem. Soc. 1951, $73,4301$.

(52) Zakrzewska, A.; Kolehmainen, E.; Valkonen, A.; Haapaniemi, E.;

Rissanen, K.; Chęcińska, L.; Ośmiałowski, B. J. Phys. Chem. A 2012, 117, 252.

(53) Xu, S.; Evans, R. E.; Liu, T.; Zhang, G.; Demas, J. N.; Trindle, C. O.;

Fraser, C. L. Inorg. Chem. 2013, 52, 3597.

(54) Yu, Y.-H.; Descalzo, A. B.; Shen, Z.; Röhr, H.; Liu, Q.; Wang, Y.-W.; Spieles, M.; Li, Y.-Z.; Rurack, K.; You, X.-Z. Chem.-Asian J. 2006, 1, 176.

(55) Hecht, M.; Fischer, T.; Dietrich, P.; Kraus, W.; Descalzo, A. B.;

Unger, W. E. S.; Rurack, K. ChemistryOpen 2013, 2, 25.

1109.

(56) Bura, T.; Retailleau, P.; Ulrich, G.; Ziessel, R. J. Org. Chem. 2011, 76,

(57) Ono, M.; Watanabe, H.; Kimura, H.; Saji, H. ACS Chem. Neurosci.

2012, 3, 319 .

(58) Lager, E.; Liu, J.; Aguilar-Aguilar, A.; Tang, B. Z.; Peña-Cabrera, E. J. Org. Chem. 2009, 74, 2053. $65,727$.

(59) Angulo, G.; Grampp, G.; Rosspeintner, A. Spectrochim. Acta A 2006,

(60) Birks, J. B.; Dyson, D. J. Proc. R. Soc. Lond. A 1963, 275, 135.

(61) Grabowski, Z. R.; Rotkiewicz, K.; Rettig, W. Chem. Rev. 2003, 103, 3899.

(62) Wiggins, P.; Williams, J. A. G.; Tozer, D. J. J. Chem. Phys. 2009, 131, 091101.

(63) Guido, C. A.; Mennucci, B.; Jacquemin, D.; Adamo, C. Phys. Chem. Chem. Phys. 2010, 12, 8016.

(64) Barfield, M.; Fagerness, P. J. Am. Chem. Soc. 1997, 119, 8699.

(65) Laurent, A. D.; Jacquemin, D. Int. J. Quantum. Chem. 2013, 113,

2019.

(66) Jacquemin, D.; Perpète, E. A.; Ciofini, I.; Adamo, C.; Valero, R.; Zhao, Y.; Truhlar, D. G. J. Chem. Theory Comput. 2010, 6, 2071.

(67) Silva-Junior, M. R.; Schreiber, M.; Sauer, S. P. A.; Thiel, W. J. Chem. Phys. 2008, 129, 104103. 
(68) Chibani, S.; Le Guennic, B.; Charaf-Eddin, A.; Laurent, A. D.; Jacquemin, D. Chem. Sci. 2013, 4, 1950.

(69) Le Guennic, B.; Chibani, S.; Charaf-Eddin, A.; Massue, J.; Ziessel, R.; Ulrich, G.; Jacquemin, D. Phys. Chem. Chem. Phys. 2013, 15, 7534.

(70) Chibani, S.; Charaf-Eddin, A.; Le Guennic, B.; Jacquemin, D. J. Chem. Theory Comput. 2013, 9, 3127.

(71) Er, J. C.; Tang, M. K.; Chia, C. G.; Liew, H.; Vendrell, M.; Chang, Y.T. Chem. Sci. 2013, 4, 2168.

(72) Jin, J.-L.; Li, H.-B.; Geng, Y.; Wu, Y.; Duan, Y.-A.; Su, Z.-M.

ChemPhysChem 2012, 13, 3714.

(73) Chibani, S.; Le Guennic, B.; Charaf-Eddin, A.; Maury, O.; Andraud, C.; Jacquemin, D. J. Chem. Theory Comput. 2012, 8, 3303.

(74) Cammi, R.; Mennucci, B. J. Chem. Phys. 1999, 110, 9877.

(75) Chibani, S.; Budzak, S.; Medved, M.; Mennucci, B.; Jacquemin, D. Phys. Chem. Chem. Phys. 2014, 16, 26024.

(76) Frisch, M. J.; Trucks, G. W.; Schlegel, H. B.; Scuseria, G. E.; Robb, M. A.; Cheeseman, J. R.; Scalmani, G.; Barone, V.; Mennucci, B.; Petersson, G. A.; Nakatsuji, H.; Caricato, M.; Li, X.; Hratchian, H. P.; Izmaylov, A. F.; Bloino, J.; Zheng, G.; Sonnenberg, J. L.; Hada, M.; Ehara, M.; Toyota, K.; Fukuda, R.; Hasegawa, J.; Ishida, M.; Nakajima, T.; Honda, Y.; Kitao, O.; Nakai, H.; Vreven, T.; Montgomery, J., J. A. ; Peralta, J. E.; Ogliaro, F.; Bearpark, M.; Heyd, J. J.; Brothers, E.; Kudin, K. N.; Staroverov, V. N.; Kobayashi, R.; Normand, J.; Raghavachari, K.; Rendell, A.; Burant, J. C.; Iyengar, S. S.; Tomasi, J.; Cossi, M.; Rega, N.; Millam, J. M.; Klene, M.; Knox, J. E.; Cross, J. B.; Bakken, V.; Adamo, C.; Jaramillo, J.;

Gomperts, R.; Stratmann, R. E.; Yazyev, O.; Austin, A. J.; Cammi, R.; Pomelli, C.; Ochterski, J. W.; Martin, R. L.; Morokuma, K.; Zakrzewski, V. G.; Voth, G. A.; Salvador, P.; Dannenberg, J. J.; Dapprich, S.; Daniels, A. D.; Farkas, O.; Foresman, J. B.; Ortiz, J. V.; Cioslowski, J.; Fox, D. J. In Gaussian 09, Revision A.02; Gaussian, Inc.: Wallingford CT, 2009.

(77) Petrenko, T.; Neese, F. J. Chem. Phys. 2007, 127, 164319.

(78) Savarese, M.; Aliberti, A.; De Santo, I.; Battista, E.; Causa, F.; Netti, P. A.; Rega, N. J. Phys. Chem. A 2012, 116, 7491. 